オキナエビ Nephropsis stewarti Wood-MAson

(DECAPODA, NEPHROPIDAE) の水槽内での生態

\author{
岩田雄治 ${ }^{1}$, 杉田治男 ${ }^{2}$, 出口吉昭 ${ }^{2} \cdot$ Fred I. KАмEмото ${ }^{3}$ \\ ${ }^{1}$ 日本動物植物専門学院, ${ }^{2}$ 日本大学農獣医学部水産学科, ${ }^{3}$ 八ワイ大学動物学科
}

\title{
THE HABITS BEHAVIOR OF LOBSTERETTE NEPHROPSIS STEWARTI \\ Wood-MASON (DECAPODA, NEPHROPIDAE) REARED IN AN AQUARIUM
}

\author{
Yuji Imata, ${ }^{1}$ Haruo Sugita, ${ }^{2}$ Yoshiaki Deguchi, ${ }^{2}$ \\ and Fred. I. Камғмото ${ }^{3}$ \\ ${ }^{1}$ Japan Animal and Plant Academy, ${ }^{2}$ Department of Fisheries, Nihon University, \\ ${ }^{3}$ Department of Zoology, University of Hawaii, Manoa
}

\begin{abstract}
Abstruct: The lobsterette Nephropsis stewarti beronging to the family Nephropidae, were reared in the aquarium to observe habitat behavior of redused eye crustacea.

Observations carried out during 1982 to 1984. All the specimens collected at $350-400 \mathrm{~m}$ depth of Suruga Bay, off Heda Mura, Shizuoka prefecture, Japan were carried to Shimoda Marine Station Nihon University, Shimoda-Shi, Shizuoka and reared in the 1000 liter round shaped tank with running sea water. Water temperature kept at $10-12^{\circ} \mathrm{C}$.

The bottom of reared tank covered with fine sand. Alive starfish caught simultaneously, frozen fish and krill, alive seaurchin, artificial diet for carp were fed.

Four lobsterette specimens were reared and most longest surviving period was 112 days. Remarkable habitat were, they did not show any respons to the light and walked around on the bottom through day and night but never burrowed like other animal of the Family Nephropidae.

Of the diets examined, only the starfish was fed by animals. Although the feeding behavior was not observed directly.
\end{abstract}

オキナエビ Nephropsis stewarti はアカザエビ科 Nephropidae に属し，相模湾や駿河湾な どの水深 400-500 $\mathrm{m}$ に生息し（三宅 1982），他にインド洋からあ知られている（Alcock 1894, - 99, 1902)。

本種の形態はアカザェビ Metanephrops japonicus に類似しているが，鋏脚，頭胸甲およ び腹節が細毛に覆われ，複眼に色素はなく痕跡的であるなどの特徴を有している。しかしアカ ザェビと比べて，水産的価值が低いことなどの理由から，生態に関する知見にそしい。本研究 


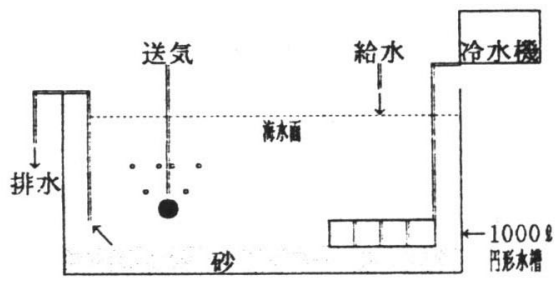

図 1 オキナエビの飼育水槽.

The rearing tank for $N$. stewarti.

ではオキナェビを水槽内での飼育を試み，生態について観察し検討した。

\section{実験材料および方法}

実験は 1982 年 11 月から 1984 年 5 月にかけて静岡県下田市の日本大学下田臨海実験所で 行った。実験材料のオキナエビは, 同県下田村沖の駿河湾の水深約 $350 \mathrm{~m}$ から底曳網で採集 された。採集されたエビは水温約 $10^{\circ} \mathrm{C}$ に保ったまま輸送し， 1000 凤 円形パンライト水槽に収 容した。水槽の海水は流下式で, 底には砂を敷き水温は冷水機で $10-12^{\circ} \mathrm{C}$ に調整した (図 1)。

餌としてムラサキウニ Anthocidaris crassispina, バフンウニ Hemicentrotus pulcherrimos, 冷凍オキアミ Euphausia superperba, 冷凍アジ Trachursus japonicus およびサバ Pneumatophorus japonicus, コイ用ペレット（メーカー不明）の他，底曳網で同時に採集さ れたオキギス Glossanodon fasiciatus およびヒトデ類も与えた。なおヒトデは生きたまま水 槽に投入し，種類については戸田沖で多量に採集されるものを選び特に同定しなかった。

水槽は日中は間接太陽光，日没後夜間 21 時まで $40 \mathrm{~W}$ 蛍光灯 4 灯で照明した。観察は昼夜， 特に消燈後の観察む随時行った。

\section{実 験 結 果}

オキナエビは, 海面の水温が $15^{\circ} \mathrm{C}$ 以上の時は採集後輸送前に死亡した。輸送中の死亡個体 はなかった。

実験期間中に合計 4 尾のオキナェビを飼育し，生存期間は最長 112 日，平均 76 日であった。 体長が $47 \mathrm{~mm}$ の個体では性別が不明であった。1 個体が冷水機の故障で死亡した（表 1 ）。

水槽内でのオキナエビは巣穴を掘ったり物陰などに隠れたりせず休みなく水槽内を歩き回っ たため, 底砂の表面には 1 昼夜で無数の歩行痕跡が観察された。歩行時の姿勢は, 進行方向へ 鋏脚を突き出し，触角で周囲を探り，尾節は持ち上げていた（図 2 )。

歩行中前方の物体を触角で探知すれば向きを変えたが, 触角に触らなければ他の生物でも踏 み越えていくのが観察された。活動時に室内の照明を点滅させたり光を当てても反応はなく, 活動に昼夜の差異は見いだせなかった。また本種は大きな鋏脚を持つが，鋏脚を用いて争うこ とはなかった。 
Table 1.オキナエビの生存期間书よび死亡原因

Rearing term and cause of death $N$. stewarti in the rearing tank.

\begin{tabular}{rcccc}
\hline \hline Rearing term & Sampling bate & Sex & Body length & Cause of death \\
\hline 71 days & $11 / 5 / 1982$ & female & $14 \mathrm{~mm}$ & Starvation* $^{*}$ \\
31 days & $12 / 26 / 1983$ & male & $13 \mathrm{~mm}$ & Starvation* $^{*}$ \\
112 days & $12 / 26 / 1983$ & male & $11 \mathrm{~mm}$ & Starvation* $^{*}$ \\
90 days & $3 / 22 / 1984$ & unknown & $4.7 \mathrm{~mm}$ & Accident $^{* *}$ \\
\hline
\end{tabular}

* estimated

** trouble on cooling system
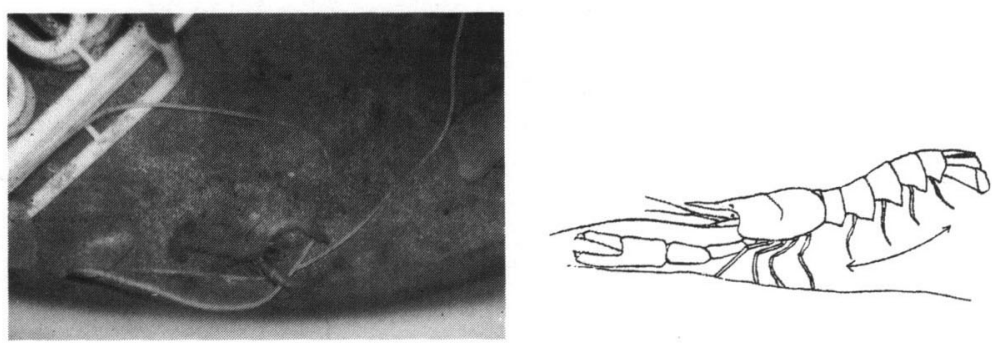

図 2 水槽内を歩行するオキナエビ（図左）および歩行時の側面模式図（図右）.

Walking $N$. stewarti in the tank bottom (left) and side view (right).

与えた餌はどれも触角または歩脚に触れた場合歩行を止めて口に運んだが，すぐに落として 再び歩きだしたので摂餌したと認め難かった。またその際, 第 1 鋏脚は使用しなかった。

最も長く生存した個体と同じ水槽に収容したヒトデの腕の先端に, 食害されたと見られる形 跡が観察され，その後は腕 4 本を失い死亡した（図 $3 \mathrm{~A}-\mathrm{C}$ )。別の個体では腕 2 本を失った状 態が観察された（図 3 D)。しかし今回の実験期間中にオキナエビがヒトデを捕食する行動は 直接観察できなかった。

実験期間中に脱皮成長した個体は観察されなかった。

考 察

本種は光に対する反応が認められず，光をほとんど感じないと推測された。また昼夜で行動 に差が見られないことから，行動に昼夜のリズムも認め得なかった。

アカザェビ科の生態について，ノルウェーロブスターNephrops norvegicus の海底での観 察では個体ごとに单穴を掘って生息し (FigueIREdo and Thomas 1967, Chapman and RiCE 1971, RICE and CHAPMAN 1971), ミナミアカザェビ Metanephrops thomsoni の水槽 内での観察（内田，道津 1973）およびウミザリガニ Homarus americanus の海岸での観察 （橘高 1980）においても同様の報告がなされている。オキナェビと同様に複眼の退化した種類 については, Holthuis (1974）が大西洋海域のアカザエビ上科, オサテエビ科 Thaumasto- 


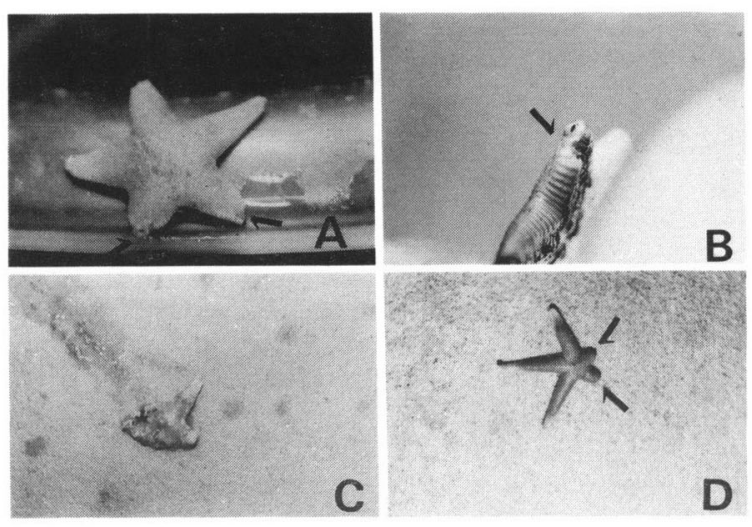

図 3 ヒトデに観察された食害の痕跡.

$\mathrm{A}$ ：腕の一部に見られる欠損 (矢印).

B：欠損部に見られるかじり取られた跡 (矢印).

$\mathrm{C}:$ 同個体の死亡時の状況.

D : 別のヒトデに見られた腕の欠損 (矢印).

Starfish bitten off by $N$. stewarti.

A : Bites on the starfish (arrows).

B : Magnified a bite (arrow).

C : Died starfish.

$\mathrm{D}$ : Bites on the other starfish (arrows).

chelidae および Nephoberinae 科 Acanthacaris caeca の生態に関して, 写真などから泥の 海底に巣穴を作って生活している BORROWER であると報告しており, 巣穴を作るのはこれら に共通の習性であると考えられる。

しかしながらオキナエビの場合，これらとは異なり非常に活動的で巣穴を作ることがなかっ た。

オキナェビの食性について，ヒトデ以外に捕食した形跡が認められないことから，動物遺骸 などではなく生物捕食性があり，動きの鈍い棘皮動物などのベントスを摂䭒していると考えら れる。

以上からオキナエビの生態を推測すると, 常時海底を徘徊し, 餌と思われる生物を手当たり 次第摂飰しているものと考えられる。

飼育したオキナェビの死亡原因について, 飼育装置故障により 1 個体が死亡したが, 他はヒ トデを食害したとみられる個体の生存期間が最長であったことと死亡個体の消化管の内容物が なかった点から, 餓死であると考えられた（表 1)。

要

オキナエビを水槽内で飼育し，その生態について知見を得た。水槽内のオキナエビは近縁種 のアカザェビと異なり巣穴を掘ったり, 物陰に隠れる, 縄張りを作るといった習性はなく, 常 に水槽底を徘徊していた。餌を探知すれば反応し, 口に運ぶが摂餌はされないが, 同じ海底か 
ら採集されたヒトデを捕食した形跡がありこうしたベントスを探しまわりながら生息してい ることが示唆された。

謝 辞

本研究を行うにあたり, 有益な御助言を睗った日本大学農獣医学部下田臨海実験所元所長日 比谷 京博士ならびに東 禎三教授に深謝する。また実験材料の採集に御助力を賜った日本大学 商学部の安原 健充教授ならびに短期大学部の室伏 誠教授そして静岡県田方郡戸田村役場の勝 呂 博氏を初めとする職員の方に感謝の意を表する。

\section{文・献}

Alock, A. 1894. Natural history notes from H. M. Indian marine survey steamer "Investigator” , Commander R.F. Hoskyn, R. N. commanding., Ser. $2(1)$., On the results of deep sea dredging the season $1890-1891$ (cont.). Ann. Nat. Hist., Ser. 6(13) : 225-245.

1899 A summary of the deep sea zoological work of the Royal Indian marine survey ship Investigater from 1884 to 1897. Sci. Mem. med. off. Army India., 2 : 1-49. 1902. A naturalist in Indian Seas. 328 p.

Chapman, C. T. and Rice, A. L. 1971. Some direct ovservations on the ecology and behavior of the Norway lobster Nephrops norvegicus. Mar. Biol., 10:321-329.

Figueiredo, M. J. and Thomas, H. J. 1967. Nephrops norvegicus (Linaeus) 1758 leach a review. Oceanogr. Mar. Biol. Ann. Rev., 5 : 371-407.

Holthuis, L. B. 1974. The lobsters of the Super family Nephropidea of the Atrantic Ocean (Crustacea : Decapoda). Bull. Mar. Sci., 24(4): 723-884.

橘高二郎 1980. Homarus の養殖. 海洋科学, $12: 872-884$.

三宅貞祥, 1983. 現色日本大型甲殼類図鑑 I . 保育社, 大阪：261 pp.

Rice, A. L. and Chapman, C.T. 1971. Observations on the burrows and burrowing behavior of two mud dwelling decapod crustaceana, Nephrops norvegicus and Goneplax rhomboides. Mar. Biol., $10: 330-342$.

内田隆信, 道津喜衛 1973. 練習船長崎丸の採集物報告一 4, ミナミアカザ (アカザエビ科) のふ化と幼 生飼育. 長崎大学水産学部研報, $36: 23-35$. 